Article

\title{
Application of Emergy Analysis to the Sustainability Evaluation of Municipal Wastewater Treatment Plants
}

\author{
Shuai Shao ${ }^{1,2,3, *}$, Hailin $\mathrm{Mu}^{1, *}$, Fenglin Yang ${ }^{3}$, Yun Zhang ${ }^{3}$ and Jinhua $\mathrm{Li}^{3}$ \\ 1 Key Laboratory of Ocean Energy Utilization and Energy Conservation of Ministry of Education, \\ School of Energy and Power Engineering, Dalian University of Technology, Linggong Road 2, Dalian 116024, \\ Liaoning, China \\ 2 School of Innovation and Entrepreneurship, Dalian University of Technology, Linggong Road 2, \\ Dalian 116024, Liaoning, China \\ 3 School of Environmental Science and Technology, Dalian University of Technology, Linggong Road 2, \\ Dalian 116024, Liaoning, China; yangfl@dlut.edu.cn (F.Y.); zhangyun@dlut.edu.cn (Y.Z.); \\ lijinhua@mail.dlut.edu.cn (J.L.) \\ * Correspondence: shaoshuai24015@mail.dlut.edu.cn (S.S.); hailinmu@dlut.edu.cn (H.M.); \\ Tel./Fax: +86-411-8470-8095 (S.S.)
}

Academic Editor: Vincenzo Torretta

Received: 17 September 2016; Accepted: 16 December 2016; Published: 24 December 2016

\begin{abstract}
Municipal wastewater treatment plants consume much energy and manpower, are expensive to run, and generate sludge and treated wastewater whilst removing pollutants through specific treatment regimes. The sustainable development of the wastewater treatment industry is therefore challenging, and a comprehensive evaluation method is needed for assessing the sustainability of different wastewater treatment processes, for identifying the improvement potential of treatment plants, and for directing policymakers, management measures and development strategies. This study established improved evaluation indicators based on Emergy Analysis that place total wastewater, resources, energy, economic input and emission of pollutants on the same scale compared to the traditional indicators. The sustainability of four wastewater treatment plants and their associated Anaerobic-Anoxic-Oxic (A2O), Constant Waterlevel Sequencing Batch Reactor (CWSBR), Cyclic Activated Sludge Technology (CAST) and Biological Aerated Filter (BAF) treatment processes were assessed in a city in northeast China. Results show that the CWSBR process was the most sustainable wastewater treatment process according to its largest calculated value of Improved Emergy Sustainable Index $\left(2.53 \times 10^{0}\right)$, followed by BAF $\left(1.60 \times 10^{0}\right)$, A2O $\left(9.78 \times 10^{-1}\right)$ and CAST $\left(5.77 \times 10^{-1}\right)$. Emergy Analysis provided improved indicators that are suitable for comparing different wastewater treatment processes.
\end{abstract}

Keywords: emergy analysis; wastewater treatment process; improvement indicator; sustainability evaluation

\section{Introduction}

Municipal wastewater treatment plants utilize specific technologies to reduce or eliminate pollutants in wastewater resulting from human activities and other sources, and therefore play a critical role in reducing water pollution. In 2015, discharge of wastewater (including industrial wastewater, municipal sewage, and pollution control facility wastewater) pollutants in China alone resulted in chemical oxygen demand (COD) emissions of 22.235 million tons and ammonia nitrogen $\left(\mathrm{NH}_{3}-\mathrm{N}\right)$ emissions of 2.299 million tons [1]. Furthermore, urbanization processes are rapidly accelerating in China, and water consumption and wastewater treatment demand are subsequently increasing. By the end of 2015, the treatment capacity of national municipal wastewater treatment plants reached 140 million cubic meters per day, cumulative wastewater disposal reached 41.03 billion cubic meters, 
and the national municipal wastewater treatment rate reached $91.97 \%$ [2]. Wastewater treatment facilities are therefore an important part of municipal construction in China.

Wastewater treatment plants consume a lot of energy, chemicals, manpower, and are associated with various environmental issues. Furthermore, they generate sludge and treated wastewater during the process of collecting, treating, and discharging municipal wastewater to acceptable permit standards. Municipal wastewater treatment plants must simultaneously consider environmental, energy and economic impacts according to municipal structures and developmental planning constraints [3], and these considerations influence the choice of treatment processes and screen wastewater treatment technologies employed. Sustainable wastewater treatment processes aiming to address the problems above include hydrodynamic cavitational technique [4], molecular imprinting [5] and microbial fuel cells [6]. The future wastewater treatment industry in China must address: (1) how to build new wastewater treatment plants with appropriate treatment processes; and (2) how to maximize the potential of existing wastewater treatment plants by implementing energy-saving and emission-reduction technologies to meet the needs of sustainable development. To achieve these aims, a systematic evaluation method is needed to determine the improvement potential of wastewater treatment plants, to evaluate the sustainability of different wastewater treatment processes, and to guide policymakers, management measures and development strategies.

The sustainable development of an industrial system (the industrial entirety with specific functions which is composed of several interactional and interdependent components) needs to be technologically feasible, environmentally friendly and economically attractive. For wastewater treatment plants, technological and environmental feasibility is dependent on adopting advanced and stable treatment processes that are appropriate for different wastewater treatments and that generate treated water meeting national discharge standards. However, a system that is technologically and environmentally feasible but not economically competitive is likely to be unsustainable.

Currently, researchers apply various methods to evaluate the resource use, energy and environmental performance of industrial systems, including Ecological Footprint Analysis [7-9], Substance Flow Analysis [10-13], Energy Flow Analysis [14-16], Exergy Analysis [17-19], Life Cycle Assessment [20-22], Emergy Analysis [23-26] and other methods. For a method to be suitable for evaluating the sustainable development of wastewater treatment processes, it needs to be possessing clear indicator system, quantifiable and able to simultaneously consider the social, economic and environmental impacts.

Emergy Analysis is a system analysis method based on energy analysis which has been widely applied to countries and regions [27-29], ecological systems [30-32], and industrial systems [33-35].

The concepts of Emergy Theory and the Emergy Analysis method were proposed by the American ecologist H.T. Odum in the 1980s. Emergy is defined as the total amount of solar energy directly or indirectly input into any given resource, product or service, in units of Solar Emjoules (sej) [36]. Different types of energy differ quantitatively and qualitatively, and they can be related using a specific conversion relationship termed solar transformity, which refers to the amount of solar energy required to form each unit of product or service. The solar emergy of a particular energy can be calculated by multiplying the basic amount of energy by its corresponding solar transformity using the expression $\mathrm{M}=\mathrm{T} \times \mathrm{B}$ [37], where $\mathrm{M}$ represents emergy in sej, $\mathrm{T}$ represents solar transformity, and B refers to the basic amount of energy. Emergy is an important object function which is used to study self-organization processes in ecological systems, ecosystem function, depicting and simulating ecosystem behavior, predicting evolutionary trends, and evaluating ecosystem sustainability [38].

Emergy Analysis introduces solar transformity into the calculation based on Emergy Theory. In order to assess the function and status of energy in a system, it is quantitatively analyzed by converting different types and levels of energy into solar emergy.

Emergy Analysis can provide a common scale for measuring and comparing different substances, energy types, environmental impacts and economic indicators. The method can therefore be used to evaluate the sustainability of wastewater treatment processes, and for determining the sustainable 
development potential of wastewater treatment systems (the entirety reasonably formed by several unit treating procedures). To date, most Emergy Analysis of wastewater treatment processes has focused on different aspects of a single process [39], and comparison of the sustainability of different treatment processes has received less attention.

The present study established improved emergy evaluation indicators (Improved Emergy Yield Ratio, Improved Environment Load Ratio, Improved Emergy Sustainable Index) for wastewater treatment systems that place total wastewater, resources, energy, economic input and emission of pollutants on the same scale compared to the traditional indicators (Emergy Yield Ratio, Environment Load Ratio, and Emergy Sustainable Index). The coastal city in northeast China studied in the present work has more than 20 large- and medium-sized wastewater treatment plants, at which the main treatment processes are Anaerobic-Anoxic-Oxic (A2O), Constant Waterlevel Sequencing Batch Reactor (CWSBR), Cyclic Activated Sludge Technology (CAST) and Biological Aerated Filter (BAF). This study focused on four wastewater treatment plants running the treatment processes described below (Cases 1-4). This method, based on emergy flow analysis per ton of wastewater treated, provides technical guidance for policymakers to compare wastewater treatment technologies for new plants, and for upgrading existing plants.

\section{Materials and Methods}

\subsection{Methods}

\subsubsection{Emergy Evaluation Indicators}

Emergy evaluation indicators are established based on the outputs of Emergy Analysis, and they can unify different types of ecological flows at the emergy scale, as and quantitatively evaluate the structure and function of a system. Emergy indicators therefore offer a useful basis for evaluating the sustainability of a system.

Traditional Emergy Evaluation Indicators

Traditional emergy indicators [37] that are suitable for evaluating ecological-economic systems are shown in Table 1, where R refers to input emergy from renewable resources in the natural environment, $\mathrm{N}$ refers to input emergy from non-renewable resources, and F represents the purchased input emergy from the socioeconomic system.

Table 1. Traditional emergy evaluation indicators and calculation formulas.

\begin{tabular}{ccc}
\hline Indicators & Formula & Implications \\
\hline Emergy Yield Ratio (EYR) & $(\mathrm{N}+\mathrm{R}+\mathrm{F}) / \mathrm{F}$ & $\begin{array}{c}\text { Emergy efficiency and economic } \\
\text { competitiveness of the system }\end{array}$ \\
\hline Environment Load Ratio (ELR) & $(\mathrm{F}+\mathrm{N}) / \mathrm{R}$ & Environmental loading exerted by the system \\
\hline Emergy Sustainable Index (ESI) & $\mathrm{EYR} / \mathrm{ELR}$ & Sustainability of the system \\
\hline
\end{tabular}

The emergy yield ratio (EYR) of the system reflects the feedback emergy from the economic system, and is a measure of how much the emergy yield contributes to the economic system. EYR is used to judge the emergy efficiency and economic competitiveness of a system based on purchased inputs. ELR (environment load ratio) is the ratio of non-renewable input emergy (including purchased emergy and emergy from non-renewable resources) to renewable resources input emergy, and this parameter denotes the pressure economic activities place on the environment. Systems should avoid a high ELR status for a long period of time in order to avoid causing irreversible functional degradation to the environment. The emergy sustainability index (ESI) is the ratio of EYR to ELR, and reflects both ecological and economic benefits in terms of the overall sustainability of the system. 
Various studies have employed emergy theory and analysis based on the indicators described above [40,41], whereas others have developed improved indicators based on traditional emergy evaluation indicators [42,43]. Industrial systems have their own characteristics compared with ecological-economic systems, therefore, it is necessary to explicit the connotation, mechanism and application situations of "emergy" in order to establish the improved and specific emergy evaluation indicators suitable for different industrial systems.

Improved Emergy Evaluation Indicators

Wastewater is the main input into the wastewater treatment system, together with auxiliary inputs from natural and social resources, while the main outputs are drainage (treated water) and sludge. It should be noted that although the discharge concentration of chemicals in the drainage must meet national standards, $\mathrm{COD}, \mathrm{NH}_{3}-\mathrm{N}$ and other pollutants present in the treated water may still impact the environment, and should therefore be taken into account in the emergy indicators.

Figure 1 shows the wastewater treatment system emergy flow diagram, in which $\mathrm{R}$ refers to renewable natural resources emergy, $\mathrm{N}$ denotes non-renewable natural resources emergy, $\mathrm{F}_{\mathrm{R}}$ refers to purchased renewable resources emergy, $\mathrm{F}_{\mathrm{N}}$ denotes purchased non-renewable resources emergy, $\mathrm{F}_{\mathrm{S}}$ refers to capital emergy, and $\mathrm{W}_{\mathrm{in}}, \mathrm{W}_{\text {out }}$ and $\mathrm{S}$ represent the emergy of wastewater input, drainage and sludge, respectively. The total input emergy of renewable natural resources, non-renewable natural resources, purchased renewable resources, purchased non-renewable resources and capital combine to support the treatment of wastewater (input) to drainage (output), while simultaneously meeting the discharge standards and generation of sludge.

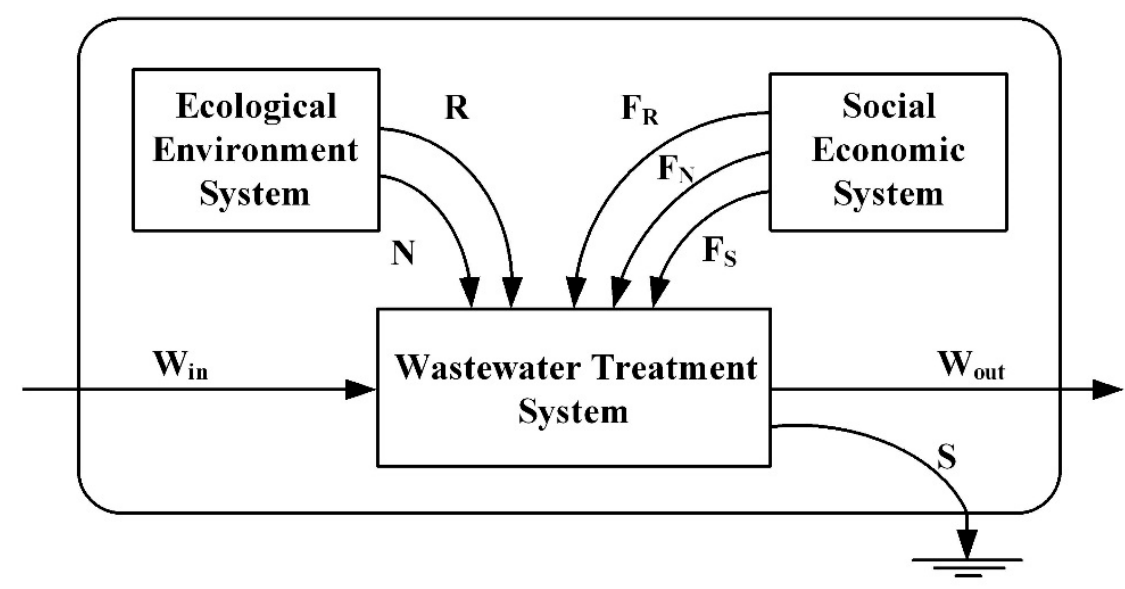

Figure 1. Emergy flow diagram of wastewater treatment systems.

(1) Improved Emergy Yield Ratio (IEYR) denotes the ratio of the net emergy input to the economic feedback emergy in the wastewater treatment system, where "input" is defined as renewable resources, non-renewable resources, capital and other types of input emergy invested in order to obtain target products or meet economic interests. Wastewater input emergy also reflects total input emergy in terms of unique raw materials used in the wastewater treatment system, whereas "net emergy" is embodied within the sludge emergy and the emergy of pollutants in drainage, both of which have a negative influence on the economics of the system and should therefore be deducted from the total input emergy. Economic feedback emergy, in addition to the emergy of purchased renewable resources, purchased non-renewable resources and capital, as well as the money invested by the economic system for sludge disposal should also be considered. The capital emergy for sludge disposal is indicated by $\mathrm{P}$, the cost of treating a unit of sludge, which equals 270 Yuan/ton [44]. 
When the net emergy input of the wastewater treatment system is larger and the total economic feedback emergy is smaller, the Improved Emergy Yield Ratio (IEYR) is greater. The expression is as follows:

$$
\text { IEYR }=\left(W_{\text {in }}+\mathrm{R}+\mathrm{N}+\mathrm{F}_{\mathrm{R}}+\mathrm{F}_{\mathrm{N}}+\mathrm{F}_{\mathrm{S}}-\mathrm{W}_{\text {out }}-\mathrm{S}\right) /\left(\mathrm{F}_{\mathrm{R}}+\mathrm{F}_{\mathrm{N}}+\mathrm{F}_{\mathrm{S}}+\mathrm{P}\right)
$$

IEYR can reflect the relationship between the emergy efficiency and the market competitiveness of different wastewater treatment processes. The larger the value, the more net emergy yield can be obtained by investing per unit of economic feedback emergy. In this case the competitiveness of the system is greater, and the economic benefit of the process is higher. Conversely, a smaller value indicates a lower emergy yield efficiency and lower competitiveness.

(2) Improved Environment Load Ratio (IELR) reflects the impact on the environment and the resource dependence of the main operation. The dependence on resources can be divided into positive benefit and negative benefit, where positive benefit refers to the dependence on renewable resources, and negative benefit reflects the dependence on non-renewable resources and capital. The impact on the environment caused by the output of drainage and sludge both fall into the negative benefit category, since industrial discharge and pollutants have a negative impact on the environment.

IELR equals the ratio of the sum of non-renewable natural resources emergy, purchased non-renewable resources emergy, capital emergy, sludge emergy and the emergy of pollutants in drainage over the sum of renewable natural resources emergy and purchased renewable resources emergy. This parameter describes the effect that the wastewater treatment system has on the local environmental ecosystem. The expression is as follows:

$$
\operatorname{IELR}=\left(\mathrm{N}+\mathrm{F}_{\mathrm{N}}+\mathrm{F}_{\mathrm{S}}+\mathrm{W}_{\text {out }}+\mathrm{S}\right) /\left(\mathrm{R}+\mathrm{F}_{\mathrm{R}}\right)
$$

IELR represents the negative impact on the environment caused by non-renewable resources consumption, economic burden and waste discharge. The larger the value of this parameter, the pressure on the surrounding environment is greater. Conversely, a smaller value indicates less pressure on the surrounding environment, in cases where the system has a more eco-friendly operational mode, and the local surroundings have adequate time and space to dilute the environmental impact and can recycle resources.

(3) Improved Emergy Sustainable Index (IESI) denotes the ratio of the Improved Emergy Yield Ratio (IEYR) and the Improved Environment Load Ratio (IELR). This composite indicator reflects the emergy yield efficiency under a certain environmental load, and can simultaneously evaluate the sustainability of different wastewater treatment processes. The expression is as follows:

$$
\mathrm{IESI}=\mathrm{IEYR} / \mathrm{IELR}
$$

IESI reflects the sustainability of the wastewater treatment system, and a larger value indicates a higher level of sustainability.

The formula comparison of the traditional and improved emergy evaluation indicators is shown in Table 2.

Table 2. Formula comparison of traditional and improved emergy evaluation indicators.

\begin{tabular}{cccc}
\hline Indicators & Formula & Indicators & Formula \\
\hline EYR & $(\mathrm{N}+\mathrm{R}+\mathrm{F}) / \mathrm{F}$ & IEYR & $\left(\mathrm{W}_{\text {in }}+\mathrm{R}+\mathrm{N}+\mathrm{F}_{\mathrm{R}}+\mathrm{F}_{\mathrm{N}}+\mathrm{F}_{\mathrm{S}}-\mathrm{W}_{\text {out }}-\mathrm{S}\right) /\left(\mathrm{F}_{\mathrm{R}}+\mathrm{F}_{\mathrm{N}}+\mathrm{F}_{\mathrm{S}}+\mathrm{P}\right)$ \\
ELR & $(\mathrm{F}+\mathrm{N}) / \mathrm{R}$ & IELR & $\left(\mathrm{N}+\mathrm{F}_{\mathrm{N}}+\mathrm{F}_{\mathrm{S}}+\mathrm{W}_{\text {out }}+\mathrm{S}\right) /\left(\mathrm{R}+\mathrm{F}_{\mathrm{R}}\right)$ \\
ESI & EYR $/$ ELR & IESI & IEYR $/$ IELR \\
\hline
\end{tabular}




\subsubsection{Environmental Impact Emergy of Pollutants in Drainage}

Drainage outputs may contain different types of pollutants such as $\mathrm{COD}, \mathrm{BOD}_{5}, \mathrm{NH}_{3}-\mathrm{N}$ and TP. Furthermore, even the input wastewater treated by the wastewater treatment system may cause pollution to the environment when the concentration of drainage pollutants is greater than the environmental background concentration. Water in the natural environment decreases the concentration of pollutants through autopurificaton and dilution, and this reduces damage to the environment. Therefore, the impact of discharge pollutants on the environment can be calculated in terms of the emergy associated with dilution of pollutants to their environmental background concentration [45]. The expression for calculating the water requirement for diluting pollutants is as follows:

$$
\mathrm{M}_{\mathrm{w}, \mathrm{i}}=\mathrm{d} \times\left(\mathrm{W}_{\mathrm{i}} / \mathrm{c}_{\mathrm{i}}\right)-\mathrm{M}_{\mathrm{w}}
$$

In this expression, $\mathrm{M}_{\mathrm{w}, \mathrm{i}}$ refers to the water requirement for diluting pollutants in units of $\mathrm{g}$, $\mathrm{d}$ denotes the density of water in units of $1 \times 10^{6} \mathrm{~g} / \mathrm{m}^{3}, \mathrm{~W}_{\mathrm{i}}$ refers to the discharge quantity of pollutant $i$ in units of $g, c_{i}$ denotes the environmental background concentration of pollutant $i$ in units of $g / \mathrm{m}^{3}$, and $\mathrm{M}_{\mathrm{W}}$ refers to the total discharge quantity of the wastewater treatment system in units of $\mathrm{g}$.

Table 3. Environmental safety concentrations for selected pollutants.

\begin{tabular}{ccccc}
\hline Item & COD & BOD $_{\mathbf{5}}$ & $\mathbf{N H}_{\mathbf{3}} \mathbf{- N}$ & $\mathbf{T P}$ \\
\hline Concentration $(\mathrm{mg} / \mathrm{L})[46]$ & 15 & 3 & 0.15 & 0.02 \\
\hline
\end{tabular}

In our calculations, we adopted the environmental safety concentrations of different types of pollutants stipulated by regulations in China (Table 3) rather than the environmental background concentrations due to the difficulty of accessing actual environmental background concentration data. The expression used to calculate the emergy of the water requirement for diluting pollutants is as follows:

$$
\mathrm{ECEW}_{\mathrm{i}}=\mathrm{M}_{\mathrm{w}, \mathrm{i}} \times 4.92 \mathrm{~J} / \mathrm{g} \times 4.48 \times 10^{4} \mathrm{sej} / \mathrm{J}
$$

In this expression, $\mathrm{ECEW}_{\mathrm{i}}$ refers to the emergy consumption of diluting the emission of water pollutant $i$ in units of sej, the Gibbs free energy of water is $4.92 \mathrm{~J} / \mathrm{g}$, and the emergy transformity of surface water is $4.48 \times 10^{4} \mathrm{sej} / \mathrm{J}$. Since different types of pollutants are diluted by water simultaneously, we selected the maximal emergy value of a certain pollutant $\left(E C E W_{\max }\right)$ as the environmental impact emergy of all pollutants in drainage.

\subsection{Materials}

\subsubsection{Description of the Study Objects}

Current municipal wastewater treatment processes adopted in China include $\mathrm{A} / \mathrm{O}, \mathrm{A} 2 \mathrm{O}$, Oxidation Ditch (OD), SBR, and Biofilms and their variants [47]. Emergy Analysis was performed for all four cases studied in present work using actual (collected) production data, natural conditions and economic indicators. The basic information for each case is described as follows:

Case 1: The Anaerobic-Anoxic-Oxic (A2O) process. This process involved a complete denitrification and dephosphorization regime based on the biological environment and alternating anaerobic, anoxic and aerobic reactions. The appropriate reaction conditions for denitrification and dephosphorization are required in the anaerobic and anoxic steps, respectively, and reaction conditions must also be conducive for treating COD and BOD in the aerobic steps. The wastewater treatment capacity of Case 1 was 30,000 $\mathrm{m}^{3} /$ day, the occupied area was 4.8 hectares, and the sludge yield per day was $14,280 \mathrm{~kg}$.

Case 2: The Constant Waterlevel Sequencing Batch Reactor (CWSBR) process. This process overcomes the disadvantages of intermittent inflow, intermittent drainage and waterlevel sequencing 
changes by retaining the advantages of the traditional SBR process and combining with constant waterlevel sequencing and continuous operation throughout the entire wastewater treatment process. The wastewater treatment capacity of Case 2 was $30,000 \mathrm{~m}^{3} /$ day, the occupied area was 3.5 hectares, and the sludge yield per day was $9540 \mathrm{~kg}$.

Case 3: The Cyclic Activated Sludge Technology (CAST) process. This process is renowned for its sludge sedimentation and dehydration performance. Wastewater is treated repeatedly by aeration, precipitation and skimming, and sludge inverse and discharge systems are incorporated at the end of the wastewater treatment system. The wastewater treatment capacity of Case 3 was $80,000 \mathrm{~m}^{3} /$ day, the occupied area was 2.5 hectares, and the sludge yield per day was $21,280 \mathrm{~kg}$.

Case 4: The Biological Aerated Filter (BAF) process. This process utilizes a denitrifying biological filter and applies a new microbial adhesion wastewater treatment technology to accomplish biological treatment and solid-liquid separation simultaneously. The equipment required for this treatment is compact, biochemical reactions and filtration occur in the same unit, the occupied area is reduced due to not requiring a secondary sedimentation tank, and the filter needs aeration in order to biologically oxidize organic compounds and ammonia nitrogen. The wastewater treatment capacity of Case 4 was $120,000 \mathrm{~m}^{3}$ / day, the occupied area was 3.5 hectares, and the sludge yield per day was 58,440 kg.

The main treatment procedures of wastewater and sludge of the four cases are shown in Table 4 .

Table 4. Main treatment procedures of wastewater and sludge of the four cases.

\begin{tabular}{cccccc}
\hline \multirow{2}{*}{ Case No. } & \multicolumn{2}{c}{ Wastewater Treatment } & \multicolumn{2}{c}{ Sludge } \\
\cline { 2 - 6 } & Preliminary & Secondary & Tertiary & Treatment & Disposal \\
\hline \multirow{2}{*}{1} & $\begin{array}{c}\text { Coarse and Fine Screens, } \\
\text { Grit Chamber }\end{array}$ & $\begin{array}{c}\text { A2O Process, } \\
\text { Secondary } \\
\text { Sedimentation Tank }\end{array}$ & $\begin{array}{c}\text { Advanced } \\
\text { Treatment }\end{array}$ & $\begin{array}{c}\text { Thickening, } \\
\text { Dewatering }\end{array}$ & $\begin{array}{c}\text { Outward } \\
\text { Transport }\end{array}$ \\
\hline \multirow{2}{*}{$\begin{array}{c}\text { Coarse and Fine Screens, } \\
\text { Aerated Grit Chamber }\end{array}$} & CWSBR Process & Disinfected & Dewatering & $\begin{array}{c}\text { Outward } \\
\text { Transport }\end{array}$ \\
\hline \multirow{2}{*}{$\begin{array}{c}\text { Fine Screen, } \\
\text { Vortex Grit Chamber }\end{array}$} & CAST Process & $\begin{array}{c}\text { Advanced } \\
\text { Treatment }\end{array}$ & $\begin{array}{c}\text { Stabilization, } \\
\text { Thickening, } \\
\text { Dewatering }\end{array}$ & $\begin{array}{c}\text { Outward } \\
\text { Transport }\end{array}$ \\
\hline & $\begin{array}{c}\text { Coarse, Intermediate } \\
\text { and Fine Screens, } \\
\text { Vortex Grit Chamber, } \\
\text { Sedimentation Tank }\end{array}$ & BAF Process & $\begin{array}{c}\text { Ultraviolet, } \\
\text { Disinfected }\end{array}$ & Dewatering & $\begin{array}{c}\text { Outward } \\
\text { Transport }\end{array}$ \\
\hline
\end{tabular}

\subsubsection{Process Flow Diagram}

Process flow diagrams for the four wastewater treatment Processes are shown in Figures 2-5.

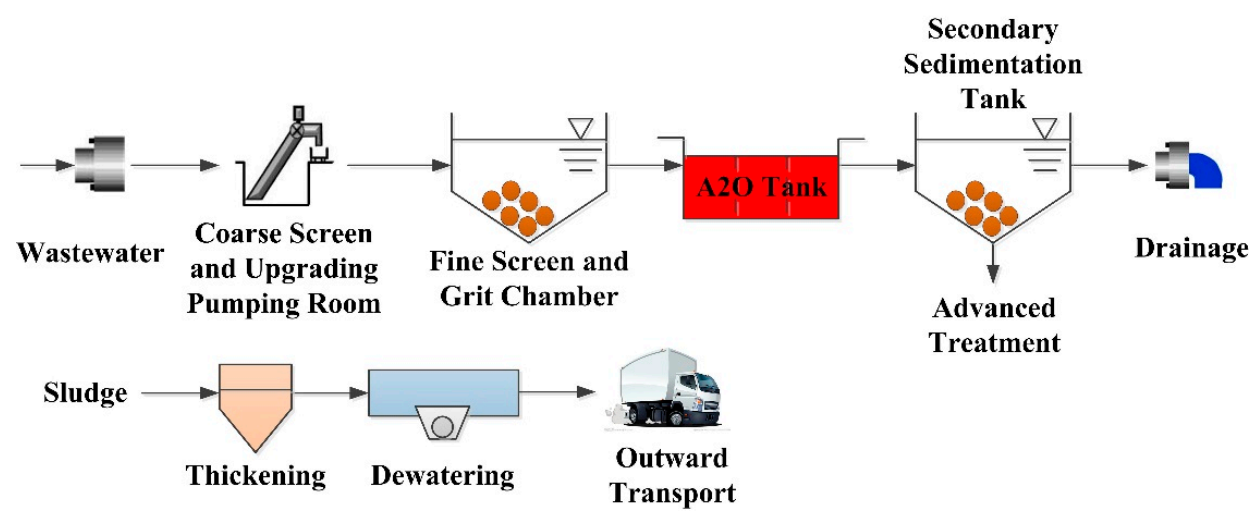

Figure 2. Flow diagram for the Anaerobic-Anoxic-Oxic (A2O) process. 


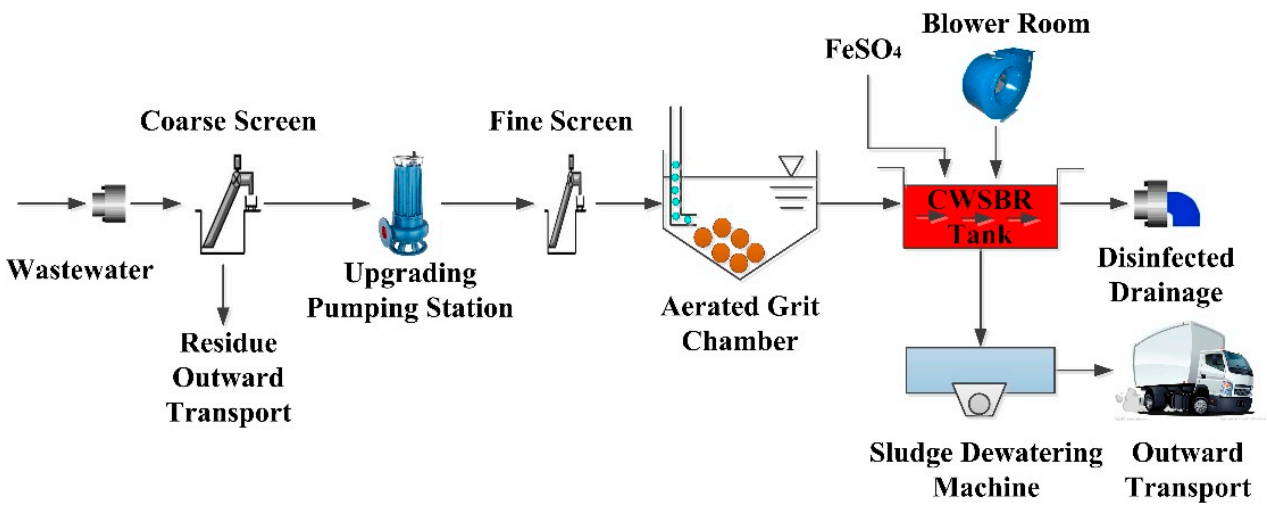

Figure 3. Flow diagram for the Constant Waterlevel Sequencing Batch Reactor (CWSBR) process.

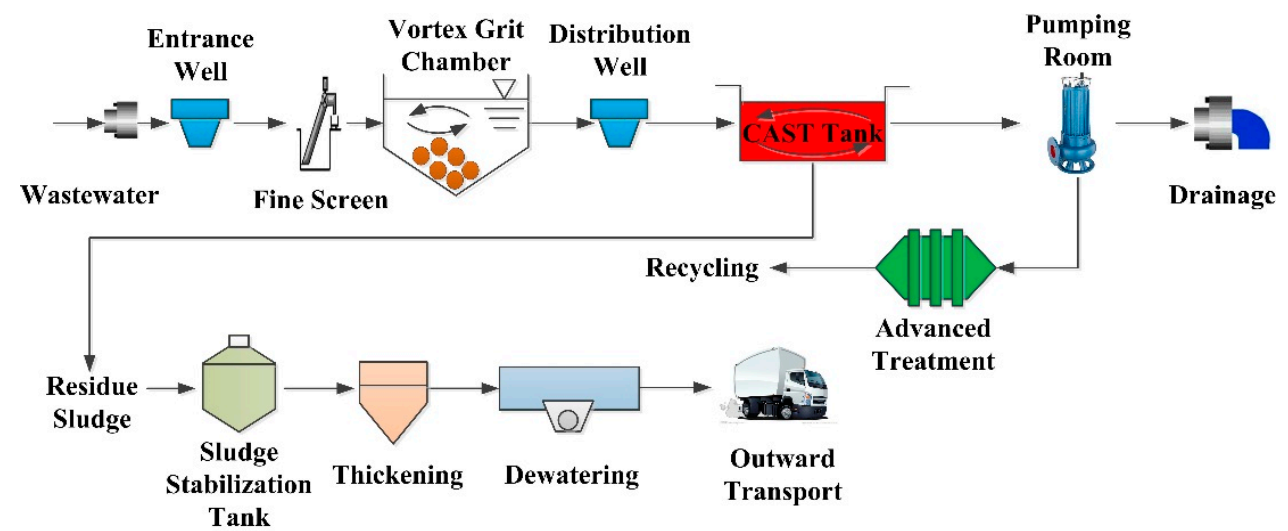

Figure 4. Flow diagram for the Cyclic Activated Sludge Technology (CAST) process.

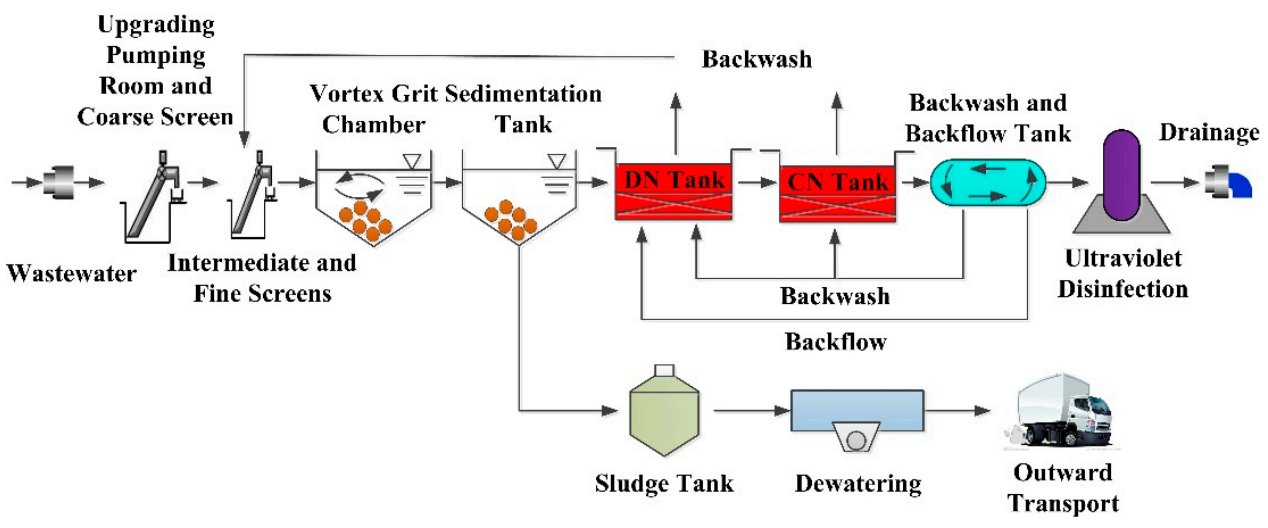

Figure 5. Flow diagram for the Biological Aerated Filter (BAF) process.

\subsubsection{Basic Natural, Economic and Technical Data}

The data used in this study were derived from actual operational wastewater treatment plants. All four plants studied were situated in the same city and were close geographically, therefore the same set of natural conditions were used for all calculations and analysis. Specifically, the annual average precipitation was $658.6 \mathrm{~mm}$, the average wind speed was $4.4 \mathrm{~m} / \mathrm{s}$, the relative humidity was $68 \%$, the average sunshine duration was $2650 \mathrm{~h}$, and the annual average evaporation was $1615 \mathrm{~mm}$.

The main economic and technical indicators of the four cases are shown in Table 5. 
Table 5. Main economic and technical indicators of the four cases.

\begin{tabular}{ccccc}
\hline Case No. & $\begin{array}{c}\text { Working Time } \\
\text { (Days/Year) }\end{array}$ & $\begin{array}{c}\text { Manpower } \\
\text { (Persons) }\end{array}$ & $\begin{array}{c}\text { Investment } \\
\text { (Ten Thousand Yuan/Year) }\end{array}$ & $\begin{array}{c}\text { Cost } \\
\text { (Ten Thousand Yuan/Year) }\end{array}$ \\
\hline 1 & 360 & 35 & 531.93 & 1343.42 \\
2 & 360 & 20 & 220.55 & 584.14 \\
3 & 360 & 30 & 469.07 & 1310.00 \\
4 & 360 & 44 & 535.35 & 1456.97 \\
\hline
\end{tabular}

The design discharge standards of the four cases all met the national wastewater discharge primary standards (GB18918-2002) [48]. Case 1 met the primary B standards while Cases 3 and 4 met the primary A standards, and Case 2 broadly met the discharge standards for $\mathrm{NH}_{3}-\mathrm{N}$ based on primary $\mathrm{B}$ standards. The specific input and output water quality indicators of the four cases were derived from actual operation data meeting the design discharge standards, as shown in Table 6.

Table 6. Input and output water quality indicators based on actual operation of the four cases.

\begin{tabular}{cccccc}
\hline Case No. & Input/Output & $\begin{array}{c}\mathbf{B O D}_{5} \\
(\mathbf{m g} / \mathbf{L})\end{array}$ & $\begin{array}{c}\text { COD } \\
(\mathbf{m g} / \mathbf{L})\end{array}$ & $\begin{array}{c}\mathbf{N H}_{3}-\mathbf{N} \\
(\mathbf{m g} / \mathbf{L})\end{array}$ & $\begin{array}{c}\mathbf{T P} \\
(\mathbf{m g} / \mathbf{L})\end{array}$ \\
\hline \multirow{2}{*}{1} & Input & 180 & 360 & 35 & 5 \\
& Output & 10 & 50 & $5(8)$ & 0.5 \\
\hline \multirow{2}{*}{2} & Input & 200 & 400 & 30 & 3 \\
& Output & 10 & 50 & $5(8)$ & 0.5 \\
\hline \multirow{2}{*}{3} & Input & 150 & 350 & 26 & 3 \\
& Output & 20 & 60 & 15 & 1 \\
\hline \multirow{2}{*}{4} & Input & 180 & 400 & 25 & 3.5 \\
& Output & 20 & 60 & 8 & 1 \\
\hline
\end{tabular}

\subsubsection{Synthesized Emergy System Diagram}

The synthesized emergy system diagram of the wastewater treatment system was drawn based on the Energy System Language Legend [37] introduced by Odum. It includes technological processes and data collected on substances, energy, currency and other information shown in Figure 6. It should be noted that "Wastewater Treatment System" was replaced by each of the four treatment processes described above during analysis.

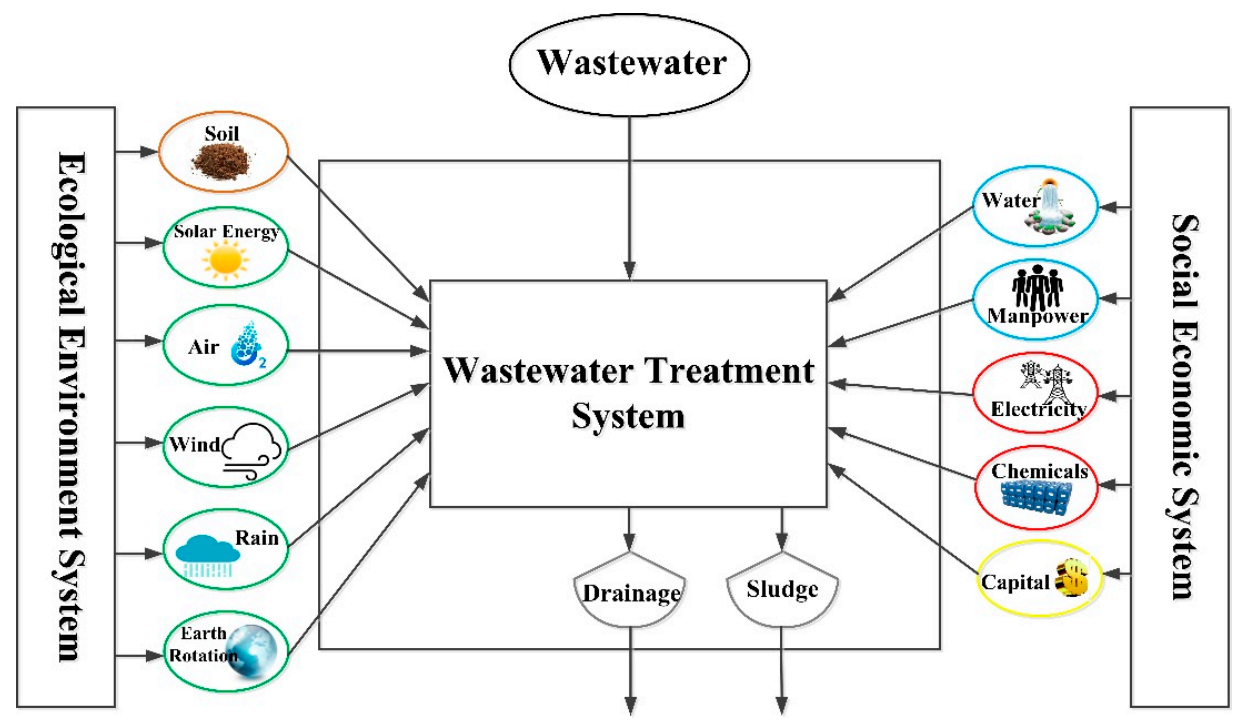

Figure 6. Diagram of the synthesized emergy system for wastewater treatments. 


\section{Results and Discussions}

\subsection{Results}

\subsubsection{Results of Emergy Analysis}

The ECEW values of drainage pollutants (Table 7) were calculated according to Equations (4) and (5), and Table 6.

Table 7. ECEW values of drainage pollutants.

\begin{tabular}{cccccc}
\hline Case No. & $\begin{array}{c}\text { ECEW }_{\text {COD }} \\
\text { (sej/Year) }\end{array}$ & $\begin{array}{c}\text { ECEW }_{\text {BOD5 }} \\
\text { (sej/Year) }\end{array}$ & $\begin{array}{c}\text { ECEW }_{\text {NH }_{3}-\mathbf{N}} \\
\text { (sej/Year) }\end{array}$ & $\begin{array}{c}\text { ECEW }_{\text {TP }} \\
\text { (sej/Year) }\end{array}$ & $\begin{array}{c}\text { ECEW }_{\text {max }} \\
\text { (sej/Year) }\end{array}$ \\
\hline 1 & $5.55 \times 10^{18}$ & $5.55 \times 10^{18}$ & $1.25 \times 10^{20}$ & $5.71 \times 10^{19}$ & $1.25 \times 10^{20}$ \\
2 & $5.55 \times 10^{18}$ & $5.55 \times 10^{18}$ & $1.25 \times 10^{20}$ & $5.71 \times 10^{19}$ & $1.25 \times 10^{20}$ \\
3 & $1.90 \times 10^{19}$ & $3.60 \times 10^{19}$ & $6.28 \times 10^{20}$ & $3.11 \times 10^{20}$ & $6.28 \times 10^{20}$ \\
4 & $2.86 \times 10^{19}$ & $5.40 \times 10^{19}$ & $4.98 \times 10^{20}$ & $4.67 \times 10^{20}$ & $4.98 \times 10^{20}$ \\
\hline
\end{tabular}

Tables S1-S4 list the main resources and energy inputs and outputs of each wastewater treatment system, and the emergy of disposing wastewater in units of per ton, for the different treatments. Different units of ecological flows were converted to common solar emergy units based on the corresponding transformities of different kinds of resources and energy. Transformities used in this study are as described by H.T. Odum and other emergy researchers [37,42,49-52]. Transformities of substances with similar properties were applied in instances where actual transformities values were unknown. The emergy inventory of each wastewater treatment system is discussed in the Supplementary Materials.

\subsubsection{Emergy Flows Analysis}

Elaborated data of emergy flows for each case are shown in Figure 7.

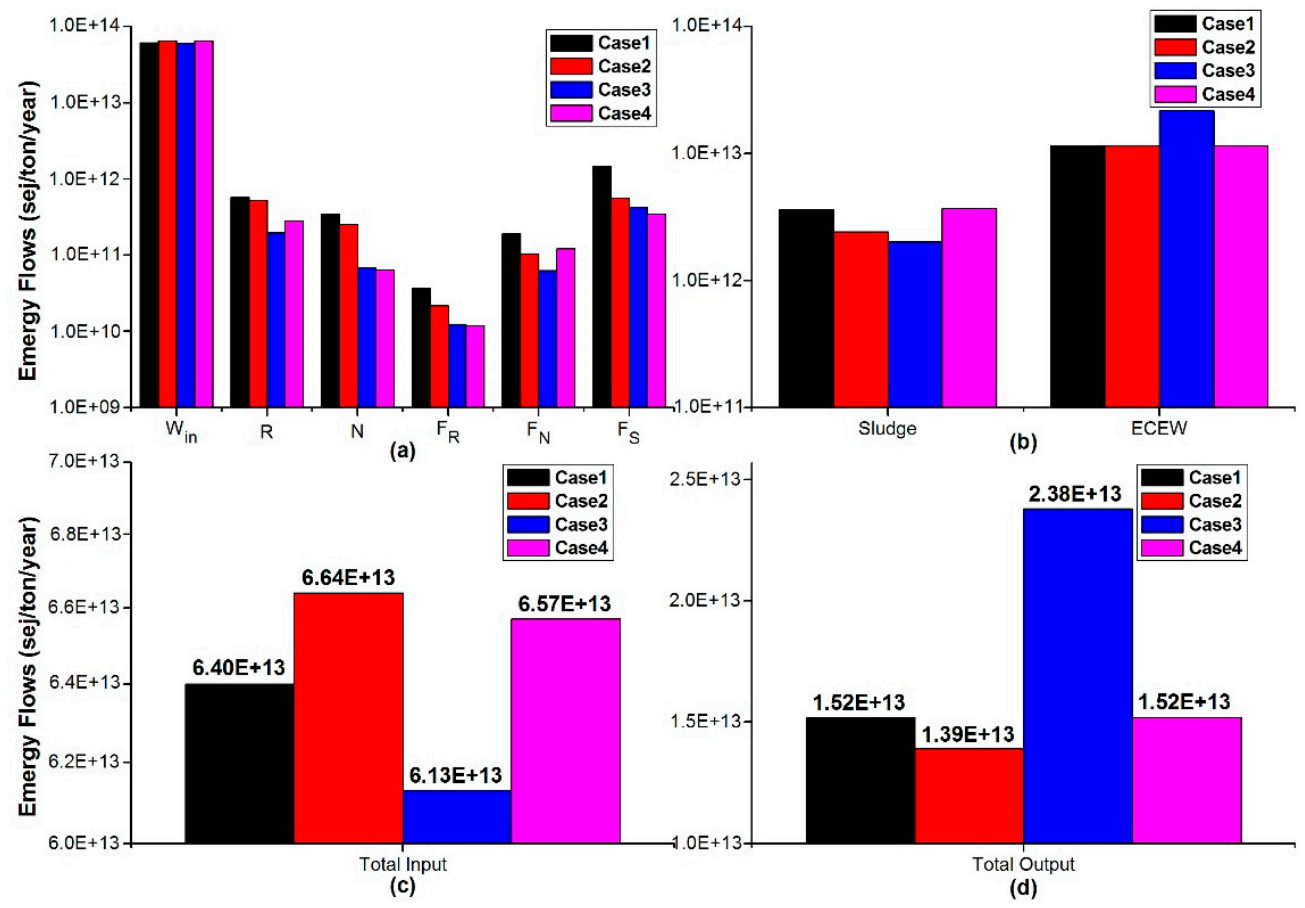

Figure 7. Elaborated data of emergy flows: (a) Input emergy flows for each case; (b) Output emergy flows for each case; (c) The total input emergy flow; and (d) The total output emergy flow. 
In terms of input emergy flow, the total input emergy of Case 2 was the highest of the four cases, with a value of $6.64 \times 10^{13} \mathrm{sej} /$ ton/year, followed by Case 4 and Case 1, with values of $6.57 \times 10^{13} \mathrm{sej} /$ ton/year and $6.40 \times 10^{13} \mathrm{sej} /$ ton/year, respectively, while Case 3 had the smallest total input emergy value of $6.13 \times 10^{13} \mathrm{sej} / \mathrm{ton} /$ year. The total input emergy of wastewater treatment systems is composed of $\mathrm{W}_{\text {in }}, \mathrm{R}, \mathrm{N}, \mathrm{F}_{\mathrm{R}}, \mathrm{F}_{\mathrm{N}}$ and $\mathrm{F}_{\mathrm{S}} . \mathrm{W}_{\mathrm{in}}$ was highest for Cases 2 and $4\left(6.49 \times 10^{13} \mathrm{sej} /\right.$ ton/year $)$, and lowest for Case $3\left(6.05 \times 10^{13} \mathrm{sej} /\right.$ ton/year $) . \mathrm{R}$ and $\mathrm{F}_{\mathrm{N}}$ emergy inputs were largest for Case $1\left(5.79 \times 10^{11} \mathrm{sej} /\right.$ ton/year and $1.91 \times 10^{11} \mathrm{sej} /$ ton/year, respectively $)$ and smallest for Case $3\left(1.98 \times 10^{11} \mathrm{sej} /\right.$ ton/year and $6.25 \times 10^{10} \mathrm{sej} / \mathrm{ton} /$ year, respectively). Similarly, N, $F_{R}$ and $F_{S}$ were all largest in Case $1\left(3.48 \times 10^{11} \mathrm{sej} /\right.$ ton/year, $3.69 \times 10^{10} \mathrm{sej} / \mathrm{ton} /$ year and $1.46 \times 10^{12} \mathrm{sej} /$ ton/year, respectively) but were smallest in Case $4\left(6.34 \times 10^{10} \mathrm{sej} /\right.$ ton/year, $1.18 \times 10^{10} \mathrm{sej} /$ ton/year and $3.48 \times 10^{11} \mathrm{sej} /$ ton/year, respectively)

In terms of output emergy flow, the total output emergy of Case 3 was largest, with the value of $2.38 \times 10^{13} \mathrm{sej} /$ ton/year, followed by Cases 1 and 4 (both $1.52 \times 10^{13} \mathrm{sej} /$ ton/year), and smallest for Case $2\left(1.39 \times 10^{13} \mathrm{sej} /\right.$ ton/year). The total output emergy of all four cases is composed of the sludge emergy and the ECEW of drainage. Regarding the sludge emergy output, this was highest in Case 4 $\left(3.69 \times 10^{12} \mathrm{sej} /\right.$ ton/year $)$, closely followed by Case $1\left(3.62 \times 10^{12} \mathrm{sej} / \mathrm{ton} /\right.$ year $)$, and was lowest for Case $3\left(2.02 \times 10^{12} \mathrm{sej} /\right.$ ton/year). Meanwhile, ECEW was highest for Case $3\left(2.18 \times 10^{13} \mathrm{sej} / \mathrm{ton} /\right.$ year $)$ and comparable $\left(1.15 \times 10^{13} \mathrm{sej} / \mathrm{ton} /\right.$ year $)$ for the other three cases.

\subsubsection{Emergy Indicators Analysis}

Wastewater input emergy accounts for over $90 \%$ of the total input emergy, due to the nature of wastewater treatment systems. Therefore, the wastewater input emergy was excluded during emergy flow proportion analysis in order to more accurately compare the relative proportion of other types of input emergy flows. The relative proportions of emergy flows for each case are listed in Table 8.

Table 8. Emergy flow contributions for the four cases (\%).

\begin{tabular}{ccccc}
\hline Item & Case 1 & Case 2 & Case 3 & Case 4 \\
\hline $\mathrm{R}$ & 22.16 & 35.70 & 25.85 & 34.20 \\
$\mathrm{~N}$ & 13.30 & 17.31 & 8.87 & 7.65 \\
$\mathrm{~F}_{\mathrm{R}}$ & 1.41 & 1.48 & 1.62 & 1.42 \\
$\mathrm{~F}_{\mathrm{N}}$ & 7.30 & 7.14 & 8.17 & 14.72 \\
-Electricity Emergy & 7.30 & 5.93 & 8.04 & 11.80 \\
-Chemicals Emergy & - & 1.21 & 0.13 & 2.92 \\
$\mathrm{~F}_{\mathrm{S}}$ & 55.83 & 38.37 & 55.49 & 42.01 \\
\hline
\end{tabular}

The $\mathrm{F}_{\mathrm{S}}$ emergy flow accounted for the largest proportion of input emergy flow in all four cases (Case $2=38.37 \%$; Case $4=42.01 \%$; Case $3=55.49 \%$; Case $1=55.83 \%$ ). The R emergy flow was the second highest input emergy flow contributor in all four cases, and this was significantly higher for Case $2(35.70 \%)$ and Case $4(34.20 \%)$ than for Case $3(25.85 \%)$ and Case $1(22.16 \%)$. The proportion of $\mathrm{N}$ emergy flow for Cases $1-3(13.30 \%, 17.31 \%$ and $8.87 \%)$ was larger than the contribution made by $\mathrm{F}_{\mathrm{N}}$ emergy flow $(7.30 \%, 7.14 \%$ and $8.17 \%)$, whereas the $\mathrm{N}$ emergy flow of Case $4(14.72 \%)$ was higher than the $\mathrm{F}_{\mathrm{N}}$ emergy flow $(7.65 \%)$. Within the $\mathrm{F}_{\mathrm{N}}$ emergy flow parameter, the electricity emergy flow made the largest contribution in Case $4(11.80 \%)$ and the smallest contribution in Case $2(5.93 \%)$, and this parameter also had the largest chemicals emergy flow proportion (Case $4=2.92 \%$ ), followed by Case 2 $(1.21 \%)$, while Cases 1 and 3 had a smaller chemicals emergy flow proportion. Finally, the contribution of $F_{R}$ emergy to input emergy flow was minimal in all four cases (Case $3=1.62 \%$; Case $2=1.48 \%$; Case $4=1.42 \%$; Case $1=1.41 \%$ ).

It can be seen from the input emergy flows (not including wastewater emergy input) that in all four cases, the $\mathrm{F}_{\mathrm{S}}$ emergy input made the largest contribution, followed by the R emergy input and $\mathrm{N}$ and $F_{N}$ emergy inputs, while the $F_{R}$ emergy input had minimal impact on the total input emergy. 
The improved emergy evaluation indicators and the order of sustainability of each case are listed in Table 9. IEYR values ranged between $2.72 \times 10^{1}$ and $8.53 \times 10^{1}$, and were largest in Case 4, followed by Cases 2, 3 and 1 . The emergy efficiency and economic competitiveness of the four treatment processes are therefore ordered Case $4>$ Case $2>$ Case $3>$ Case 1 . IELR values ranged between $2.73 \times 10^{1}$ and $1.16 \times 10^{2}$, and were ordered Case $2<$ Case $1<$ Case $4<$ Case 3, suggesting Case 2 placed the least pressure on the surrounding environment, while Case 3 had the largest impact. IESI values ranged between $5.77 \times 10^{-1}$ and $2.53 \times 10^{0}$ and were ordered Case $2>$ Case $4>$ Case 1 $>$ Case 3. The CWSBR process used in Case 2 was therefore the most sustainable, while the CAST process used in Case 3 was the least sustainable process employed in the four cases. The overall order of sustainability for the four wastewater treatment processes was CWSBR $>$ BAF $>$ A2O $>$ CAST.

Table 9. Improved emergy evaluation indicators for the four cases.

\begin{tabular}{cccccc}
\hline \multirow{2}{*}{ Case No. } & Process & \multicolumn{2}{c}{ Improved Emergy Indicator } & \multirow{2}{*}{$\begin{array}{c}\text { Sustainability } \\
\text { Order }\end{array}$} \\
\cline { 3 - 5 } & & IEYR & IELR & IESI & 3 \\
\hline 1 & A2O & $2.72 \times 10^{1}$ & $2.79 \times 10^{1}$ & $9.78 \times 10^{-1}$ & 1 \\
2 & CWSBR & $6.90 \times 10^{1}$ & $2.73 \times 10^{1}$ & $2.53 \times 10^{0}$ & 4 \\
3 & CAST & $6.69 \times 10^{1}$ & $1.16 \times 10^{2}$ & $5.77 \times 10^{-1}$ & 2 \\
4 & BAF & $8.53 \times 10^{1}$ & $5.34 \times 10^{1}$ & $1.60 \times 10^{0}$ & \\
\hline
\end{tabular}

\subsection{Discussions}

This study attempted to establish improved emergy evaluation indicators for different wastewater treatment processes based on existing emergy indicators and the results of four case studies.

Case 1 employed the A2O process and was ranked third based on IESI value. Even though the scale of this treatment scale was not particularly large, the contribution from the capital emergy $\mathrm{F}_{\mathrm{S}}$ $(55.83 \%)$ was the largest of the four cases. regarding emergy flow, the electricity emergy and capital emergy indicators of Case $1\left(1.91 \times 10^{11} \mathrm{sej} /\right.$ ton/year and $1.46 \times 10^{12} \mathrm{sej} /$ ton/year, respectively $)$ were the largest of the four processes, mainly because the $\mathrm{A} 2 \mathrm{O}$ process involves increased investment and energy consumption due to the addition of sludge recirculation and internal reflux systems. However, the $\mathrm{A} 2 \mathrm{O}$ process can be improved by energy-saving and consumption-reducing processes by adjusting methods and controlling aeration [53]. One improvement is reducing the aeration length by transforming the aerobic zone into the anoxic zone, which reduces energy consumption by decreasing aeration. Additionally, strict control of DO quantity in the aeration zone can minimize waste caused by excessive aeration.

The CWSBR process employed in Case 2 had the largest IESI value and hence the highest sustainability of the four processes. Compared with the other three processes, CWSBR relies more on renewable natural resources input emergy $\mathrm{R}(35.70 \%)$, and renewable resources emergy $\mathrm{R}$ and non-renewable resources emergy $\mathrm{N}$ inputs are well balanced in this process. The contributions from both electricity emergy (5.93\%) and capital emergy (38.37\%) are minimal in all four cases. Regarding emergy flow, the total waste emergy flow output was the smallest for the CWSBR process $\left(1.39 \times 10^{13} \mathrm{sej} /\right.$ ton/year, and sludge emergy output and electricity emergy input were also relatively small $\left(2.41 \times 10^{12} \mathrm{sej} /\right.$ ton/year and $8.68 \times 10^{10} \mathrm{sej} /$ ton/year, respectively). This can be explained by the characteristics of the CWSBR process. Firstly, this process improves on the conventional SBR process by switching form a variable waterlevel to a constant waterlevel mode of operation with the help of the reciprocating motion of a hydro sail. This modification allows the CWSBR process to periodically accomplish the entire process of filling, stirring, aeration, precipitation and decanting with continuous input and output water in a single pond. Secondly, this process reduces the hydraulic loss and energy consumption used during constant waterlevel decanting. The CWSBR process therefore covers a smaller area and involves higher system integration, stronger impulsion load resistance, and 
lower sludge retention, and the number of ponds can be increased or decreased according to water quality and quantity, which avoids unnecessary energy consumption.

The CAST process employed in Case 3 improves nitrogen and phosphorus removal by increasing sludge recirculation compared with the conventional SBR process. This process had the smallest IESI value and hence the lowest sustainability of the four processes. Regarding emergy flow, both electricity emergy $\left(6.16 \times 10^{10} \mathrm{sej} /\right.$ ton/year $)$ and capital emergy $\left(4.25 \times 10^{11} \mathrm{sej} / \mathrm{ton} /\right.$ year $)$ inputs were lower than Cases 1 and 2, because the CAST process has no primary sedimentation or secondary sedimentation tanks, and involves a higher degree of automation and thus less capital investment. Meanwhile, the ECEW of drainage $\left(2.18 \times 10^{13} \mathrm{sej} /\right.$ ton/year $)$ for the CAST process was markedly higher than for the other three processes. Regarding the relative emergy proportions, the CAST process relied more on capital emergy $(8.04 \%)$ and electricity emergy $(55.49 \%)$ than the other three processes, but less on renewable natural resources emergy $\mathrm{R}(25.85 \%)$. To improve the CAST process, a blower with better adjustment should be utilized, or combinations of blowers could be used to facilitate easier control, which would likely save energy and reduce consumption. Additionally, stricter control of the water discharge quality could decrease the emission of $\mathrm{NH}_{3}-\mathrm{N}$ and reduce the discharge of other pollutants in drainage.

The sustainability of the BAF process employed in Case 4 was ranked second in terms of IESI value. Capital emergy $\mathrm{F}_{\mathrm{S}}\left(3.48 \times 10^{11} \mathrm{sej} /\right.$ ton/year $)$ input was the lowest of the four processes, but electricity emergy was the highest of the four processes $\left(9.78 \times 10^{10} \mathrm{sej} /\right.$ ton/year), accounting for $11.80 \%$. This is mainly because the size of the filler particles used in the BAF process are generally smaller, and the filter therefore reaches the designed head loss in a shorter time period when the amount of suspended solids (SS) in the input water is high, which inevitably leads to frequent backwash and higher energy consumption. The purchased chemicals emergy of Case 4 was $2.42 \times 10^{10} \mathrm{sej} / \mathrm{ton} /$ year, accounting for $2.92 \%$ of the total emergy input, and both values are larger than the other three processes. Meanwhile, the sludge emergy output was a relatively high $3.69 \times 10^{12} \mathrm{sej} /$ ton/year, because the BAF process must remove the chemicals added to remove SS in the primary sedimentation tank in order to prevent suspended particles from clogging the filter during operation. This increases the cost of chemicals and sludge produced by adding chemicals and precipitation. Improvements could be made by incorporating technologies and methods that enhance the performance of filler particles. Additionally, selection of suitable pretreatment technologies to match the BAF process could provide further improvements that would allow better control of backwash, reduce energy consumption and decrease the addition of $\mathrm{FeCl}_{3}$. In addition, since sludge quantity affects the dosage of chemicals needed, particularly during sludge bulking, the stability of the biochemical system should receive special attention in order to avoid or minimize sludge bulking.

\section{Conclusions}

This study established improved emergy evaluation indicators for wastewater treatment systems, and evaluated the sustainability of four wastewater treatment plants and their typical treatment processes (A2O, CWSBR, CAST, and BAF) in a city in northeast China. Improvement measures were subsequently suggested that may overcome existing problems in the wastewater treatment processes based on the results of Emergy Analysis. The conclusions are as follows:

(1) This study successfully established improved emergy evaluation indicators (IEYR, IELR, and IESI) introducing $\mathrm{W}_{\text {in }}, \mathrm{F}_{\mathrm{R}}, \mathrm{F}_{\mathrm{N}}, \mathrm{F}_{\mathrm{S}}, \mathrm{W}_{\text {out }}, \mathrm{S}$ and $\mathrm{P}$ into the formulas of traditional emergy indicators (EYR, ELR, and ESI), as the traditional indicators were not suitable for evaluating wastewater treatment systems. The novel indicators can be used to comprehensively compare the sustainability of different wastewater treatment systems and processes based on wastewater emergy as a resource input and the emergy output of sludge and ECEW in drainage.

(2) In terms of input emergy flow, the total input emergy of the CWSBR process was the largest of the four, while the CAST process was the smallest, and the relative contributions of $\mathrm{R}$ and $\mathrm{F}_{\mathrm{N}}$ were largest in the $\mathrm{A} 2 \mathrm{O}$ process, and smallest in the CAST process. $\mathrm{N}, \mathrm{F}_{\mathrm{R}}$ and $\mathrm{F}_{\mathrm{S}}$ were largest in the A2O 
process and smaller in the BAF process. In terms of output emergy flow, the total output emergy was largest in the CAST process and smallest in the CWSBR process. Of the contributors to this parameter, sludge emergy output was highest in the BAF process and lowest in the CAST process, but the ECEW indicator was largest in the CAST process.

(3) Analysis of emergy flow revealed that $F_{S}$ made the biggest contribution to input emergy flows (not including wastewater emergy input) for all wastewater treatment plants and processes studied, followed by $R, N$ and $F_{N}$, while $F_{R}$ accounted for the lowest proportion of the total input emergy.

(4) Evaluation of the emergy efficiency provided information on environmental load and sustainability for the four wastewater treatment processes based on the results of the improved emergy evaluation indicators. IEYR values were ordered Case $4>$ Case $2>$ Case $3>$ Case 1. Emergy efficiency and economic competitiveness were therefore highest for the BAF process employed in Case 4. IELR values were ordered Case $2<$ Case $1<$ Case $4<$ Case 3 . The CWSBR process employed in Case 2 therefore placed the least pressure on the surrounding environment. IESI values were ordered Case $2>$ Case $4>$ Case $1>$ Case 3. The CWSBR process employed in Case 2 was therefore the most sustainable, while the CAST process employed in Case 3 was the least sustainable, and the overall order of sustainability for the four wastewater treatment processes was CWSBR $>$ BAF $>$ A2O $>$ CAST.

Therefore, under comparable effluent conditions, the CWSBR process appears to be the most appropriate choice based on emergy evaluation using the improved indicators.

Supplementary Materials: The following are available online at www.mdpi.com/2071-1050/9/1/8/s1, Table S1: Emergy inventory for Case 1, Table S2: Emergy inventory for Case 2, Table S3: Emergy inventory for Case 3, Table S4: Emergy inventory for Case 4, Table S5: List of symbols and implications.

Acknowledgments: This study was supported by the Major Science and Technology Program for Water Pollution Control and Treatment (2012ZX07202-001). The authors wish to acknowledge the anonymous reviewers for their suggestions that have greatly improved our study.

Author Contributions: S.S. designed the study, analyzed the data and wrote the manuscript; H.M. and F.Y. provided good advice throughout the paper; Y.Z. helped revise the manuscript; and J.L. did the statistics work.

Conflicts of Interest: The authors declare no conflict of interest.

\section{References}

1. Ministry of Environmental Protection of the People's Republic of China. 2015 Report on the State of Chinese Environment. Available online: http://www.mep.gov.cn/hjzl/zghjzkgb/lnzghjzkgb/201606/ P020160602333160471955.pdf (accessed on 20 May 2016).

2. China Water Web. Big Data Analysis of Wastewater Treatment in 2015. Available online: http://www.h2ochina.com/news/241538.html (accessed on 13 June 2016).

3. Huang, J.; Cha, A.P. Study on environmental impact and Countermeasures of engineering construction of wastewater treatment plants. Res. Econ. EnvProtect. 2016, 4, 104.

4. Sivakumar, M.; Pandit, A.B. Wastewater treatment: A novel energy efficient hydrodynamic cavitational technique. Ultrason. Sonochem. 2002, 9, 123-131. [CrossRef]

5. Razali, M.; Kim, J.F.; Attfield, M.; Budd, P.M.; Drioli, E.; Lee, Y.M.; Szekely, G. Sustainable wastewater treatment and recycling in membrane manufacturing. Green Chem. 2015, 17, 5196-5205. [CrossRef]

6. Wen, W.L.; Han, Q.Y.; Zhen, H. Towards sustainable wastewater treatment by using microbial fuel cells-centered technologies. Energy Environ. Sci. 2014, 7, 911-924.

7. Cerutti, A.K.; Bagliani, M.; Beccaro, G.L.; Bounous, G. Application of ecological footprint analysis on nectarine production: Methodological issues and results from a case study in Italy. J. Clean. Prod. 2010, 18, 771-776. [CrossRef]

8. Herva, M.; Hernando, R.; Carrasco, E.F.; Roca, E. Development of a methodology to assess the footprint of wastes. J. Hazard. Mater. 2010, 180, 264-273. [CrossRef] [PubMed]

9. He, C.; Wu, J.; Liu, W. Calculation method of cement ecological footprint. Acta Ecol. Sin. 2009, 29, 3549-3558.

10. Yellishetty, M.; Mudd, G.M. Substance flow analysis of steel and long term sustainability of iron ore resources in Australia, Brazil, China and India. J. Clean. Prod. 2014, 84, 400-410. [CrossRef] 
11. Arena, U.; Gregorio, F.D. A waste management planning based on substance flow analysis. Resour. Conserv. Recy. 2013, 85, 54-66. [CrossRef]

12. Gurauskiene, I.; Stasiskiene, Z. Application of material flow analysis to estimate the efficiency of e-waste management systems: The case of Lithuania. Waste Manag. Res. 2011, 29, 763-777. [CrossRef] [PubMed]

13. Torretta, V.; Ragazzi, M.; Trulli, E.; Feo, G.D.; Urbini, G.; Raboni, M.; Rada, E.C. Assessment of biological kinetics in a conventional municipal WWTP by Means of the oxygen uptake rate method. Sustainability 2014, 6, 1833-1847. [CrossRef]

14. Mohamed, Z.; Wang, X. A deterministic and statistical energy analysis of tyre cavity resonance noise. Mech. Syst. Signal Process. 2016, 70, 947-957. [CrossRef]

15. Yau, Y.H.; Lim, K.S. Energy analysis of green office buildings in the tropics-Photovoltaic system. Energ. Build. 2016, 126, 177-193. [CrossRef]

16. Peng, T.; Xu, X. An interoperable energy consumption analysis for CNC machining. J. Clean. Prod. 2016, 140, 1828-1841. [CrossRef]

17. Hou, D.; Shao, S.; Zhang, Y.; Liu, S.L.; Chen, Y.; Zhang, S.S. Exergy analysis of a thermal power plant using a modeling approach. Clean Technol. Environ. Policy 2012, 14, 805-813. [CrossRef]

18. Sui, X.W.; Zhang, Y.; Shao, S.; Zhang, S.S. Exergetic life cycle assessment of cement production process with wasteheat power generation. Energy. Convers. Manag. 2014, 88, 684-692. [CrossRef]

19. Ameri, M.; Ahmadi, P.; Khanmohammadi, S. Exergy analysis of a $420 \mathrm{MW}$ combined cycle power plant. Int. J. Energy. Res. 2008, 32, 175-183. [CrossRef]

20. Li, J.H.; Zhang, Y.; Shao, S.; Zhang, S.S. Comparative life cycle assessment of conventional and new fused magnesia production. J. Clean. Prod. 2015, 91, 170-179. [CrossRef]

21. Zhang, Y.; Liang, K.M.; Li, J.H.; Zhao, C.C.; Qu, D.L. LCA as a decision support tool for evaluating cleaner production schemes in iron making industry. Environ. Prog. Sustain. Energy 2016, 35, 195-203. [CrossRef]

22. Righi, S.; Oliviero, L.; Pedrini, M.; Buscaroli, A.; Casa, C.D. Life Cycle Assessment of management systems for sewage sludge and food waste: centralized and decentralized approaches. J. Clean. Prod. 2013, 44, 8-17. [CrossRef]

23. Li, C.F.; Cao, Y.Y. Visualization analysis of hot topics and frontiers on international emergy research. Ecol. Environ. Sci. 2014, 23, 1084-1092.

24. Brown, M.T.; Herendeen, R.A. Embodied energy analysis and emergy analysis: A comparative view. Ecol. Econ. 1996, 19, 219-235. [CrossRef]

25. Campbell, D.E.; Ohrt, A. Environmental Accounting Using Emergy: Evaluation of Minnesota; Environmental Protection Agency, Office of Research and Development, National Health and Environmental Effects Research Laboratory, Atlantic Ecology Division: Narragansett, RI, USA, 2009.

26. Brown, M.T.; Ulgiati, S. Emergy-based indices and ratios to evaluate sustainability: monitoring economics and technology toward environmentally sound innovation. Ecol. Eng. 1997, 9, 51-69. [CrossRef]

27. Lomas, P.L.; Alvarez, S.; Rodríguez, M.; Montes, C. Environmental accounting as a management tool in the Mediterranean context: The Spanish economy during the last 20 years. J. Environ. Manag. 2008, 88, 326-347. [CrossRef] [PubMed]

28. Sweeney, S.; Cohen, M.J.; King, D.; Brown, M.T. Creation of a global emergy database for standardized national emergy synthesis. In Proceedings of the 4th Biennial Emergy Research Conference, Gainesville, FL, USA, 19-21 January 2006.

29. Gao, L.H.; Gao, Q. The Emergy Analysis and sustainability evaluation of ecological economic system of coastal areas in China. Environ. Pollut. Control 2012, 34, 86-93.

30. Zhu, Y.L.; Zhou, J.; Li, S.; Liu, Y. On eco-efficiency of the agricultural eco-economic system in Hunan based the emergy theory. J. Hunan Univ. Sci. Technol. 2011, 14, 86-89.

31. Dong, X.B.; Gao, W.S.; Yan, M.C. Emergy analysis of agroecosystem productivity of Typical Valley in Loess Hilly-gully Region of the Loess Plateau: A case study in Zhifanggou Valley of Ansai County. Acta Geogr. Sin. 2004, 59, 223-229.

32. Xu, M.C. Study on sustainability of agricultural ecosystem in Liaocheng city based on emergy analysis. Tianjin Agri. Sci. 2015, 21, 29-33, 43.

33. Brown, M.T.; Ulgiati, S. Emergy evaluations and environmental loading of electricity production systems. J. Clean. Prod. 2002, 10, 321-334. [CrossRef] 
34. Marchettini, N.; Ridolfi, R.; Rustici, M. An environmental analysis for comparing waste management options and strategies. Waste Manag. 2007, 27, 562-571. [CrossRef] [PubMed]

35. Li, J.J. Emergy Account and Analysis in China's Industrial System. Master's Thesis, Nanjing University of Finance and Economics, Nanjing, China, September 2011.

36. Odum, H.T. Environmental Accounting: Emergy and Environmental Decision Making; John Wiley \& Sons: New York, NY, USA, 1996.

37. Lan, S.F.; Qin, P.; Lu, H.F. Emergy Synthesis of Ecological Economic Systems; Chemical Industry Press: Beijing, China, 2002.

38. Fu, X.; Wu, G.; Liu, Y. Analytical theories of exergy and emergy for ecological research. Acta Ecol. Sin. 2004, 24, 2621-2626.

39. Vassallo, P.; Paoli, C.; Fabiano, M. Emergy required for the complete treatment of municipal wastewater. Ecol. Eng. 2009, 35, 687-694. [CrossRef]

40. Zhang, X.X.; Ma, F. Emergy evaluation of different straw reuse technologies in northeast China. Sustainability 2015, 7, 11360-11377. [CrossRef]

41. Liu, C.; Shi, X.Y.; Qu, L.L.; Li, B.Y. Comparative analysis for the urban metabolic differences of two types of cities in the resource-dependent region based on emergy theory. Sustainability 2016, 8. [CrossRef]

42. Zhang, X.H.; Jiang, W.J.; Wu, J.; Zhang, T.H. Improved emergy indices for analyzing sewage treatment ecosystems. Resour. Sci. 2009, 31, 250-256.

43. Li, M.; Zhang, X.H.; Li, Y.W.; Xiao, H.; Qi, H.; Deng, S.H. Emergy and economic evaluations of two sewage treatment systems. Acta Ecol. Sin. 2012, 32, 6936-6945.

44. China Environment Web. How Much Does It Cost to Dispose a Ton of Sludge? Available online: http://www.cenews.com.cn/qy/qygc/201509/t20150929_797767.html (accessed on 29 September 2015).

45. Li, M.; Zhang, X.H.; Li, Y.W.; Zhang, H.; Zhao, M.; Deng, S.H. Environmental impacts of sewage treatment system based on emergy analysis. Chin. J. Appl. Ecol. 2013, 24, 488-496.

46. Ministry of Environmental Protection of the People's Republic of China. Environmental Quality Standards for Surface Water (GB3838-2002). Available online: http:/ / kjs.mep.gov.cn/hjbhbz/bzwb/shjbh/shjzlbz/ 200206/W020061027509896672057.pdf (accessed on 1 June 2002).

47. Liu, H.; Luo, L.X.; Lin, M.; Li, X.N.; Zhao, Z.Y. The present situation and development of the wastewater treatment technology in China. In Proceedings of the Academic Annual Conference of Chinese Society for Environmental Sciences, Chengdu, China, 22-23 August 2014.

48. China Water Industry Web. Discharge Standard of Pollutants for Municipal Wastewater Treatment Plant. Available online: http://www.shuigongye.com/standard/200811/2008110612041100001.html (accessed on 6 November 2008).

49. Zhao, H. Sustainability Evaluation of Hospital Sewage Treatment System Based on Emergy Theoty-Zhuokeji Health Center Sewage Treatment System as a Case. Master's Thesis, Sichuan Agricultural University, Chengdu, China, June 2013.

50. Pulselli, R.M.; Simoncini, E.; Ridolfi, R.; Bastianoni, S. Specific emergy of cement and concrete: An energy-based appraisal of building materials and their transport. Ecol. Indic. 2008, 8, 647-656. [CrossRef]

51. Li, M. Emergy Based Research for the Sustainable Development of a Livestock Sewage Treatment Plant System. Master's Thesis, Sichuan Agricultural University, Chengdu, China, June 2013.

52. Bjorklund, J.; Geber, U.; Rydberg, T. Emergy analysis of municipal wastewater treatment and generation of electricity by digestion of sewage sludge. Resour. Conserv. Recy. 2001, 31, 293-316. [CrossRef]

53. Huang, H.H.; Zhang, J.; Wen, X.H.; Gan, Y.P.; Zhou, J. Study on energy saving methods for A2O process in wastewater treatment plants. Chin. J. Environ. Eng. 2009, 3, 35-38.

(c) 2016 by the authors; licensee MDPI, Basel, Switzerland. This article is an open access article distributed under the terms and conditions of the Creative Commons Attribution (CC-BY) license (http://creativecommons.org/licenses/by/4.0/). 